\title{
Pembelajaran IPA Berbasis Pendidikan Karakter Dengan Huruf Braille Untuk Siswa Difable Netra
}

\author{
Yosi Yulizah \\ Institut Agama Islam Negeri Curup \\ chieyosi@iaincurup.ac.id
}

\begin{abstract}
One of the goals of national education is the effort to form children's character. Without exception, children who have a good sense of sight, both of whom cannot function properly, are called blind people with disabilities and also need good character education as an effort to develop the potentials that exist within them optimally and optimally. Natural education science is one of the subjects that also requires the development of character education. The data collection method uses library research, with a qualitative approach and the data source is secondary data. Furthermore, the data analysis technique is by managing data (reduction), data display, and conclusions from the final results of data collection carried out. The results of this study obtained a clear explanation of: $A$. Character education, B. Characteristics of science studies, C. Science learning, D. Science learning objectives, E. Children with special needs, F. Braille, G. Implementation of education-based science learning Braille characters for blind students can be implemented in three stages, including: 1). Planning consists of formulating learning objectives, selecting and packeaging materials by incorporating character education values into the lesson plans; 2). Implementation consists of science subjects and integration with other subjects; 3). Evaluation consists of assessment activities based on the application of character education values that are implemented on the attitudes and behavior of students with visual impairments in schools.
\end{abstract}

Keyword: Learning Science, Character Education, Difable Netra.

\begin{abstract}
Abstrak: Pendidikan nasional salah satunya tujuan adalah upaya pembentukan karakter anak. Tanpa terkecuali anak yang memiliki indera penglihatan baik kedua-duanya tidak dapat berfungsi dengan baik yang disebut difabel netra dan juga membutuhkan pendidikan baik pendidikan karakter sebagai upaya dikembangkannya potensi-potensi yang ada didalam dirinya secara maksimal dan optimal. Ilmu pendidikan alam (IPA) merupakan salah satu mata pelajaran yang juga membutuhkan pengembangan pendidikan karakter. Metode pengumpulan data menggunakan library research, dengan pendekatan kualitatif dan sumber datanya yang berupa data sekunder. Selanjutnya teknik analisis data dengan cara kelola data (reduksi), display data, dan kesimpulan dari hasil akhir pengumpulan data yang dilakukan. Hasil dari penelitian ini diperolehnya pemaparan secara jelas mengenai: A. Pendidikan karakter, B. Karakteristik kajian IPA, C. Pembelajaran IPA, D. Tujuan pembelajaran IPA, E. Anak berkebutuhan khusus, F. Huruf braille, G. Implementasi pembelajaran IPA berbasis pendidikan karakter dengan huruf braille untuk siswa difable netra bisa dilaksanakan dengan tiga tahapan, diantaranya: 1). Perencanaan terdiri dari perumusan tujuan pembelajaran, memilih dan mengemas materi dengan memasukan nilai-nilai pendidikan karakter kedalam RPP; 2). Pelaksanaan terdiri dari mata pelajaran IPA dan integrasi dengan mata pelajaran lainnya;
\end{abstract}

AR-RIAYAH : Jurnal Pendidikan Dasar vol. 5, no. 2, 2021

IAIN Curup - Bengkulu l p ISSN 2580-362X; e ISSN 2580-3611 http://journal.iaincurup.ac.id/index.php/JPD

DOI: $10.29240 /$ jpd.v\%vi\%i.3345 
3). Evaluasi terdiri dari kegiatan penilaian yang berdasarkan penerapan nilainilai pendidikan karakter yang terimplementasi pada sikap dan perilaku siswa difabel netra di sekolah.

Kata kunci: Pembelajaran IPA, Pendidikan Karakter, Difabel Netra.

\section{PENDAHULUAN}

Pendidikan secara umum bukan hanya sebagai proses penyampaian informasi dangan melalui proses belajar dan pembelajaran saja akan tetapi bisa juga diartikan sebegai proses sosialisasi baik itu sosialisai nilai, sikap, keterampilan dan pengetahuan. Sekolah merupakan salah satu tempat dalam upaya mensosialisikan nilai-nilai, Sikap, keterampilan dan pengetahuan. ${ }^{1}$ Upaya menciptakan proses pembelajaran dan suasana belajar yang dilaksanakan dengan terencana dan secara sadar yang disebut juga dengan pendidikan. Upaya dan usaha untuk mengembangkan potensi peserta didik secara aktif, mereka harus mempunyai kekuatan spiritual keagamaan, akhlak mulia, pengendalian diri, kepribadian, dan keterampilan yang dibutuhkan untuk dirinya sediri, lingkungan masyrakat, bangsa dan Negara. ${ }^{2}$

Sudah diketahui secara luas bahwa setiap orang sebagai warga negara memiliki kesempatan yang sama untuk mendapatkan pendidikan sesuai yang tertulis dalam Undang undang dasar 1945 pasal 27 ayat 1 . Dengan demikian dalam memperoleh pendidikan semua anak normal dan anak berkebutuhan khusus memiliki hak dan kesempatan yang sama. Oleh sebab itu, pelayanan pendidikan yang berkualitas dan bermutu wajib diberikan oleh negara tidak terkecuali anak istimewa yang memiliki

${ }^{1}$ Ary. H. Gunawan, Sosiologi Pendidikan: Suatu Analisa Sosiologi Tentang Pelbagai Problem Pendidikan, (Jakarta: Rineka Cipta, 2000), hlm 54-55.

${ }^{2}$ Undang - Undang No. 1 tahun 2003 tentang Sistem Pendidikan Nasional, pada Bab I pasal 1. Undang-Undang Sistem Pendidikan Nasional, (Yogyakarta: Pustaka Pelajar, 2006), hlm 3 
kekurangan dalam kemampuan (difabel).

Tak ada halangan seorang difabel dalam mencari dan menuntut ilmu pengetahuan, dikarenakan semua orang difabel memiliki kesempatan dan hak sama, hal ini telah disebutkan bahwa setiap warga yang mempunyai kelainan mental, emosional, fisik dan intelektual dan/atau social memiliki hak untuk memperoleh pendidikan khusus sesuai dengan pasal 5 ayat 2 Undang-undang Sistem Pendidikan Nasional. Anak luar biasa yang menunjukan adanya kelainan khusus yang sering didengar dengan istilah anak berkebutuhan khusus. ${ }^{3}$ Anak yang mengalami gangguan dengan tidak berfungsinya indera penglihatan (kedua-duanya) sebagai saluran dalam proses penerimaan informasi dalam kehidupan sehari-hari disebut difabel netra atau difabel netra, ini merupakan satu bagian dari anak berkebutuhan khusus. ${ }^{4}$

Meskipun anak difabel netra berbeda dengan anak-anak normal ataupun awas, mereka sama juga harus mengembangkan potensi dan kemampuan yang dimiliki secara maksimal dan optimal dengan dibutuhkannya ilmu pengetahuan dan pendidikan. Anak difabel netra juga dapat berkontribusi positif kepada dan/atau untuk masyarakat dengan melalui pemahaman pengetahuan dalam artian mereka juga memiliki kesempatan yang sama dengan anak normal lainnya. Pembelajaran IPA merupakan mata pelajaran yang sangat sering untuk diaplikasikan didalam kehidupan sehari-hari. Di sekolah dasar tujuan dari kegiatan pembelajaran supaya peserta didik mempunyai kemampuan antara lain:

3 Bandi Delpie, Pembelajaran Anak Tunagrabita: Suatu Pengantar Dalam Pendidikan Inklusi, (Bandung: Aditama, 2006), hlm 1.

4 Suljihati T. Somatri, Psikologi Anak Luar Biasa, (Bandung: Refika Aditama, 2007), hlm 65 . 
(1) memperoleh keyakinan terhadap kebesaran Tuhan Yang Maha Esa berdasarkan keindahan, keteraturan alam dan keberadaan ciptaanNya, (2) meningkatkan kesadaran untuk menghargai

Buku referensi pembelajaran IPA yang telah diterbitkan Depdiknas serta Penerbit swasta saat ini masih jarang didapat sentuhansentuhan nilai-nilai karakter seperti nilai jujur, disiplin, jujur, kerja keras, mandiri, toleransi, kreatif dan nilai nilai karakter lainnya yang dapat mengantarkan anak untuk mengagungkan ciptaan-Nya dan dapat menerapkan nilai-nilai tersebut melalui proses pembelajaran. Dampaknya penerapan nilai-nilai menjadi kering, yang seharusnya dengan melalui proses pembelajaran dan pengajaran IPA di sekolah umum ataupun sekolah inklusi dapat menerapkna nilai-nilai karakter supaya dapat tumbuh kembang dengan baik dan terlebih lagi harus kita sadari bahwa penanaman nilai-nilai karakter tidak dibebankan pada guru mata pelajaran pendidikan kewarganegaraan, pelajaran Agama, maupun mata pelajaran lainnya. Melainkan penanaman tersebut merupakan tanggung jawab semua pendidik dalam proses pembelajaran.

Sebagai penerus bangsa peserta didik wajib memiliki moral dan akhlak yang baik, supaya dapat menciptakan kehidupan berbangsa yang aman, adil dan makmur, yang merupakan tujuan dari pendidikan karakter. Tujuan Pendidikan dalam Undang-Undang Nomor 20 tahun 2003 tentang Sistem Pendidikan Nasional yang menyebutkan bahwa "Pendidikan nasional berfungsi mengembangkan kemampuan dan membentuk watak serta peradaban bangsa yang bermartabat dalam rangka mencerdaskan kehidupan bangsa, bertujuan untuk berkembangnya potensi peserta didik agar menjadi manusia yang beriman dan bertaqwa kepada Tuhan Yang Maha Esa, berakhlak mulia, 
sehat, berilmu, cakap, kreatif, mandiri dan menjadi warga negara yang demokratis serta bertanggung jawab". ${ }^{5}$

\section{METODE PENELITIAN}

Tujuan penelitian ini yaitu untuk mengetahui dan membahas apa dan bagaimana implementasi pembelajaran IPA berbasis pendidikan karakter dengan huruf braille untuk siswa difabel netra. Metode pengumpulan data menggunakan penelitian library research (kepustakaan), dengan pendekatan kualitatif dan sumber datanya yang berupa data sekunder yang merupakan data-data yang sudah ada terdahulu atau data yang sudah dikumpulkan dan disajikan oleh pihak lain. ${ }^{6}$ Selanjutnya teknik analisis data dengan cara kelola data (reduksi), display data, dan gambaran kesimpulan dari hasil akhir pengumpulan data yang dilakukan melalui studi literature/kepustakaan.

\section{PEMBAHASAN}

Dari hasil penelitian kepustakaan yang sudah dilakukan didapat data-data sesuai dari sumber sekunder ataupun penelitian-penelitian sebelumnya dapat dijelaskan sebagai berikut.

\section{A. Pendidikan Karakter}

Pendidikan karakter adalah suatu upaya penanaman nilai-nilai untuk semua peserta didik agar memiliki kesadaran, pengetahuan dan tindakan ketika mengaplikasikan nilia-nilai tersebut. ${ }^{7}$ Pendidikan karakter

${ }^{5}$ Departemen Pendidikan Nasional, Undang-Undang No 20 Tabun 2003, (Jakarta: Depdiknas, 2003)

${ }^{6}$ Suliyatno \& MM, S. Metode Penelitian Kuantitatif. (Jakarta: Rineka Cipta, 2017). hlm. 65.

7 Ahmad Muhaimin Azzet, Urgensi Pendidikan Karakter di Indonesia. (Yogyakarta: Ar-Ruzz Media, 2011), hlm. 36 
yang disebut juga dengan pendidikan budi pekerti plus. Pada dasarnya penerapan pendidikan karakter ini tidak cukup dengan pengetahuan saja dalam bertindak, karena sangat erat kaitannya dengan nilai dan norma. Oleh sebab itu, juga harus melibakan aspek perasaan saja. ${ }^{8}$

Pendidikan karakter merupakan "upaya transformatif pengetahuan dan nilai dari nilai-nilai luhur yang bersumber dari agama, budaya, dan kebangsaan." Oleh sebab itu, nilai-nilai pendidikan karakter ini bisa disebut dengan circle of instruction yang berarti pendidikan karakter yang mengandung nilai-nilai baik bersumber dari budaya, agama maupun kebangsaan. Dimana pendidikan karakter ini sudah tergambar dengan jelas pola ataupun desain pembelajarannya baik dari segi materi, proses maupun segi penilaiannya. Sebagai generasi muda bangsa Indonesia sangat membutuhkan pola sikap dan kultur yang baik sesuai dengan nilainilai pendidikan karakter dalam membangun peradaban bangsa. ${ }^{9}$

Untuk membangun generasi muda sekarang dan masa yang akan dating tidak dapat efektif lagi menerapkan pendekatan nilai-nilai pendidikan karakter terdahulu yang bersifat pendoktrinan/pencekokan dianggap sudah memadai agar mencegah terjadinya penyimpangan perilaku sesuai norma-norma yang berlaku dan dapat membentuk kemandirian. Kendati demikian, pendekatan pendidikan karakter yang bersifat pendoktrinan tidak cocok untuk diterapkan, begitupun dengan pemberian teladan, dikarenakan untuk dijadikan teladan yang tepat sangat sulit untuk ditentukan. Dengan demikian sangat perlu melakukan pendekatan komprehensif atau multipendekatan untuk penanaman nilainilai pendidikan karakter. Salah satu pendekatan komprehensif yang

\footnotetext{
${ }^{8}$ Ibid., hlm. 27

${ }^{9}$ Asmawa Sahlan dan Angga P. Teguh, Desain Pembelajaran Berbasis Pendidikan Karakter, (Yogyakarta: Ar-Ruzz Media, 2012), hlm. 33-34
} 
tepat dalam pendidikan karakter. ${ }^{10}$

Dibawah ini nilai-nilai pendidikan karakter yang telah dirilis oleh Kemendikbud sebagaimana terdapat dalam tabel 1.1

Tabel 1.1

Nilai-nilai Pendidikan Karakter Dalam Pembelajaran

\begin{tabular}{|c|c|}
\hline Nilai & Deskripsi \\
\hline Religius & $\begin{array}{l}\text { Perilaku dan sikap yang melaksankan ajaran } \\
\text { agama yang dianutnya }\end{array}$ \\
\hline Jujur & $\begin{array}{l}\text { Perilaku yang berusaha agar tindakan dan } \\
\text { perkataannya dapat dipercaya. }\end{array}$ \\
\hline Toleransi & $\begin{array}{l}\text { Sikap yang menghargai semua perbedaan } \\
\text { baik suku, pendapat, agama dan sikap taupun } \\
\text { tindakan orang lain. }\end{array}$ \\
\hline Disiplin & $\begin{array}{l}\text { Tindakan yang berperilaku selalu patuh dan } \\
\text { tertib sesuai aturan yang berlaku. }\end{array}$ \\
\hline Kerja keras & $\begin{array}{l}\text { Tindakan yang bersungguh-sungguh } \\
\text { menghadapi semua hambatan atau pun } \\
\text { rintangan dalam mengerjakan sesuatu } \\
\text { dengan sebaik-baiknya. }\end{array}$ \\
\hline Kreatif & $\begin{array}{l}\text { Melakukan sesuatu dengan berpikir agan } \\
\text { dapat menghasilkan sesuatu yang hal yang } \\
\text { baru.. }\end{array}$ \\
\hline Mandiri & $\begin{array}{l}\text { Perilaku yang tidak ingin bergantung dengan } \\
\text { orang lain dalam menyelesaikan tugas- } \\
\text { tugasnya. }\end{array}$ \\
\hline Demokratis & $\begin{array}{l}\text { Perilaku yang bersikap, berfikir, dan } \\
\text { bertindak dengan menyamakan jika hak dan } \\
\text { kewajiban dirinya sama dengan orang lain. }\end{array}$ \\
\hline Rasa ingin tahu & $\begin{array}{l}\text { Tindakan yang selalu berusaha agar dapat } \\
\text { memperoleh tentang sesuatu secara meluas } \\
\text { dan medalam melaui apa yang dipelajari, } \\
\text { dilihat ataupun didengar. }\end{array}$ \\
\hline Semangat kebangsaan & $\begin{array}{l}\text { Cara bersikap, berfikir, dan berbuat yang } \\
\text { memperlihatkan kepedulian terhadap bangsa }\end{array}$ \\
\hline
\end{tabular}

${ }^{10} \mathrm{H}$. Kirschenbaum, $100 \mathrm{~W}$ ays to Enhance V alues and Morality in School and Youth Settings, (Boston: Allyn \& Bacon, 1995), hlm. 10. 


\begin{tabular}{ll}
\hline & $\begin{array}{l}\text { baik bahasa, budaya, social, alam dan } \\
\text { ekonomi/politik. }\end{array}$ \\
\hline Menghargai prestasi & $\begin{array}{l}\text { Sikap yang memeperlihatkan penghormatan } \\
\text { dan menghargai keberhasilan yang didapat } \\
\text { diri sendiri ataupun orang lain. }\end{array}$ \\
\hline Bersahabat/komunikatif & $\begin{array}{l}\text { Tindakan yyang menunjukan rasa senang } \\
\text { dalam bekerja sama, bergaul, berkerja dan } \\
\text { berbicara terhadap orang lain. }\end{array}$ \\
\hline Cinta damai & Perkataan, sikap, dan tindakan yang baik \\
& sehingga orang lain merasa senang dan aman \\
dengan kehadiran dirinya.
\end{tabular}

Usaha dalan menanamkan nilai-nilai atau budi pekerti di SD hingga SMA dapat berjalan efektif dan efisien jikalau sudah adanya saling terhubung antara mata pelajaran agama dengan mata pelajaran lainnya. Dengan demikian nilai-nilai atau budi pekerti tidak hanya dapat dicover dalam mata pelajaran Agana ataupun PKn saja, akan tetapi dapat diintegrasikan didalam mata pelajaran umum lainnya seperti IPA, Bahas Indonesia, Olahraga, dan lainnya dengan menekankan pada muatan dan ruanglingkup lebih mendalam. Singkatnya nilai-nilai budipekerti ini bisa diperoleh dengan melalui proses kegiatan pembelajaran mata pelajaran 
umum baik melalui tema ataupun bahasa yang bisa di terima anak didik. "Oleh karena itu, setiap mata pelajaran seyogyanya tidak hanya mengandung substansi pelajaran yang bersifat kognitif, namun dibalik hal-hal yang bersifat kognitif terdapat sejumlah nilai dasar yang harus diketahui peserta didik.",11

\section{B. Karakteristik Kajian IPA}

Pembelajaran IPA yang secara langsung memberikan pengetahuan dan pengalaman untuk memahami dan menjelajahi pengetahuan alam sekitar secara alamiah dan ilmiah. Dalam memperoleh pengetahuan melalui pengamatan, eksperimen dan dedukasi supaya dapat mengumpulkan data untuk meperjelas menegenai sesuatu gejala untuk dipercaya. $^{12}$

Dengan demikian proses pembelajaran IPA sebaiknya dilakukan dalam bentuk kegiatan eksperimen atau anak-anak terjun langsung agar dapat mencoba sendiri. Baik itu menggunakan media, alat peraga dan sumber belajar yang tepat seperti modul berbasis pendidikan karakter yang berkaitan dengan kehidupan sehari-hari dengan disampaikan dengan suasana yang menyenangkan untuk siswa agar dapat mendorong rasa ingin tahu ketika proses pembelajaran sedang berlangsung.

\section{Pembelajaran IPA}

Mata Pelajaran di sekolah salah satunya yaitu "Ilmu Pengetahuan Alam/ sains (science) diambil dari kata latin scientia yang arti harfiahnya adalah pengetahuan, tetapi kemudian berkembang menjadi khusus

\footnotetext{
${ }^{11}$ Zubaedi, Pendidikan Berbasis Masyarakat Upaya Menawarkan Solusi Terbadap Bergbagai Problem Sosial, (Yogyakarta: Pustaka Pelajar, 2004), hlm. 40-41

12 Trianto, Model Pembelajaran Terpadu dalam Teori dan Praktikum,... 2007, hlm. 102.
} 


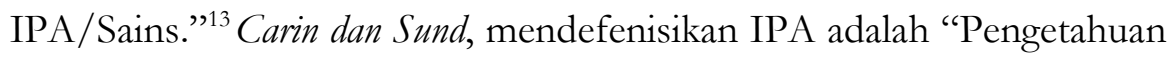
yang sistematis dan tersusun secara teratur, berlaku umum (universal), dan berupa kumpulan data hasil observasi dan eksperimen". ${ }^{14}$ Dapat disimpulkan bahwa IPA merupakan materi yang berupa kumpulan teoriteori yang sistematis dengan penerapan secara terbatas pada ilmu-ilmu alam, gejala-gejala alam, lahir/tumbuh dan perkembangan. Diamati melalui metode ilmiah eksperimen dan observasi yang mencakup semua secara kompleks dengan menuntut sikap jujur, terbuka, rasa ingin tahu dan lainnya.

Dengan demikian ketika proses pembelajaran IPA dilaksanakan maka terbukalah kesempatan untuk menumbuhkan sikap rasa ingin tahu anak dengan cara ilmiah. Dalam proses pembelajaran IPA di sekolah sebaiknya lebih banyak melibatkan anak didik dalam melakukan kegiatan yang sifatnya mengaktifkan atau mengembangkan sikap ilmiah dan keterampilan proses supaya adanya kesempatan untuk anak menerima dan mengalami perubahan secara langsung melalui eksperimen dan kegiatan praktek percobaan-percobaan.

Secara umum guru pembelajaran IPA saat ini harus memiliki wawasan luas, keterampilan mengelola metode atau media dengan handal, kreatifitas tinggi, inovatif, dan percaya diri hingga berani mengembangkan materi. Pembelajaran IPA tidak hanya mengenai penguasaan materi pengetahuan yang berupa konsep-konsep, fakta, ataupun prinsip-prinsip materi saja akan tetapi pengetahuan yang bersumber dari hasil penemuan, pembelajaran IPA ini sangat erat

13 Trianto, Wawasan Ilmu Alamiah Dasar (perspektif Islam dan Barat), Jakarta: Prestasi Pustaka, 2007), cet ke-1, hlm. 17

14 Trianto, Model Pembelajaran Terpadu dalam Teori dan Praktikum, (Jakarta: Prestasi Pustaka, 2007), hlm. 100 
kaitannya dengan bagaimana cara mencari tahu mengenai alam secara sistematis dan dapat mempelajari diri sendiri serta harapan kedepannya anak dapat mengembangkan dan menerapkan didalam kehidupannya sehari-hari.

\section{Tujuan Pembelajaran IPA}

Agar terpenuhi kebutuhan manusia didalam kehidupan sehari-hari dengan demikian menunjukan IPA sangat diperlukan. "Yang pada dasarnya pembelajaran IPA bertujuan sebagai suatu kerangka model dalam proses pembelajaran diantaranya; meningkatkan motivasi/minat belajar dan meningkatkan efisiensi dan efektivitas pembelajaran.." dipadukan konsep-konsep dengan tidak saling tumpang tindih maka pembelajaran IPA bisa menjadi lebih efektif dan efisien. Yang dapat membbuat peserta didik menjadi menjadi termotivasi untuk belajar dan mampu untuk mengaplikasikannya di kehidupan sehari-hari. ${ }^{16}$

Dengan demikina dapat ditarik kesimpulan Pembelajaran IPA merupakan suatu produk atau wadah mengaplikasikan dalam mengembangkan gagasan dan pengetahuan mengenai alam sekitar dengaan melihat keteraturan yang dapat meningkatkan keyakinan kebesaran ataupun keagungan Allah SW'T dan mampu menerapkan nilainilai dalam karakter.

\section{E. Anak Berkebutuhan Khusus}

\section{Pengertian Anak Berkebutuhan Khusus}

Mohammad Efendi menyatakan "bahwa istilah berkelainan dalam percakapan sehari-hari dikonotasikan sebagai suatu kondisi yang menyimpang dari rata-rata umumnya. Penyimpangan tersebut hlm.106.

15 Trianto, Model Pembelajaran Terpadu dalam Teori dan Praktikum,... 2007, ${ }^{16}$ Ibid., hlm. 40. 
memiliki nilai lebih atau kurang. Dalam pendidikan luar biasa atau pendidikan khusus anak berkelainan, istilah penyimpangan secara eksplisit ditunjukan kepada anak yang dianggap memiliki kelainan penyimpangan dari kondisi rata-rata anak normal umumnya, dalam hal fisik, mental maupun karakteristik perilaku sosialnya." ${ }^{17}$ Atau dengan kata lain seorang anak yang dianggap berbeda dari rata-rata umumnya, yang sebabkan oleh permasalahan kemampuan dalam berfikir, pendengaran, penglihatan, bergerak, dan sosialisasi.

Mereka yang memiliki karakteristik khusus atau istimewa secara signifikan berada jauh dari rata-rata normal pada aspek mental, fisik, motoric, indera, emosi dan social disebut dengan anak berkebutuhan khusus yang sanagat membutuhkan pelayanan khusus dan istimewa. Anak berkebutuhan khusus di Indonesia jika dihubungkan dengan kebutuhan pendidikan dapat dikelompokan menjadi 7 kelompok, yaitu: ${ }^{18}$

a. Kelompok anak Tuna netra (difabel netra) disebut bagian A

b. Kelompok anak tunarungu disebut bagian B

c. Kelompok anak tunagrahita disebut bagian $\mathrm{C}$

d. Kelompok anak tunadaksa disebut bagian D

e. Kelompok anak tuna laras disebut bagian $\mathrm{E}$

f. Kelompok anak dengan kemampuan diatas rata-rata atau superior disebut bagian $\mathrm{F}$

g. Kelompok anak tunaganda disebut bagian $\mathrm{G}$

\section{Difabel Netra / Tuna Netra}

Anak yang memiliki gangguan pada indera penglihatannya sering

17 Mohammad Efendi, Pengantar Psikopedagogik Anak Berkelainan. Jakarta: Bumi Aksara, 2006), hlm 11.

${ }^{18}$ Ibid., hlm 12. 
disebut anak tuna netra atau difabel netra, dalam cakupan setiap anak yang memiliki gangguan ini ada buta total, ada yang kemampuan melihatnya terbatas baik itu sangat terbatas ataupun kurang yang bisa memenafaatkan inderanya untuk pelaksanaan kegiatan sehari-hari terutama untuk belajar. ${ }^{19}$

Dapat disimpulkan difabel netra adalah seseorang yang mempunyai indera penglihatannya (kedua-duanya) sebagai saluran dalam proses penerimaan informasi dalam kehidupan sehari-hari sebagaimana halnya kemampuan penglihatan orang awas. Gangguan penglihatan pada anak-anak dapat diketahui melalui kondisi sebagai berikut; 1) adanya kerusakan pada susunan syaraf otak yang menghubungkan dengan indera penglihatan, 2) ketajaman dalam melihat menurun dan berkurang dibandingkan dengan ketajaman orang awas, 3) terdapat cairan tertentu yang mengakibatkan kekeruhan pada lensa mata, dan 4) syaraf otak sulit untuk mengendalikan posisi mata. Sesuai dengan kondosi-kondisi tersebut. Untuk menentukan seseorang anak yang menjadi bagian kelompok difabel netra atau tidak secara umum yaitu dilihat dari tingkat ketajaman penglihtannya.

Selain itu cara lain untuk mengetahui kedifabel netraan seorang dapat melalui tes atau biasa disebut tes snellen card. Untuk menentukan seorang anak difabel netra jika ketajaman penglihatannya kurang dari 6/21 yang berarti anak tersebut mampu membaca huruf pada jarak 6 $\mathrm{m}$ yang jika dibaca orang awas bisa dibaca pada jarak $21 \mathrm{~m}$. Berdasarkan acuan ini, anak difabel netra bisa dibagi menjadi 2 jenis, yaitu:

${ }^{19}$ T. Suljihati Somatri, Psikologi Anak. Luar Biasa,... 2007, hlm 65 
a) "Buta, bila anak sama sekali tidak memiliki kemampuan menerima rangsang cahaya dari luar (visusnya $=0$ )"

b) "Low Vision, bila anak masih mampu menerima rangsang cahaya dari luar tetapi ketajamannya lebih dari 6/21, atau jika anak hanya mampu membaca headline pada surat kabar."

Anak difable netra mempunyai karakteristik yang sangat bervariasi baik dari segi kepribadian, social, emosi, mtotorik dan pengetahuannya. Hal tersebut sangat dipengaruhi sejak kapan mereka mulai mengalami kedifabel netraan, tingkat ketajaman penglihatannya, usianya berapa, dan tingkat pendidikannya. Anak difable netra dapat melakukan kegiatan pembelajaran dan kegiatan kehidupan dengan menggunakan indera nonvisual yang berfungsi seperti indera perabaan, indera pendengaran, indera pembau, dan indera pengecap (Perasa). Sebagian siswa difabel netra memiliki kecerdasan kognitif dan tidak dipengaruhi dengan kekurangan visualnya terkecuali bagi merekayang mempunyai kekurangan atau kelainan ganda.20 Secara umum anak difabel netra ini perkembangan kognitifnya terpengaruh oleh kedifabel netraannya dan juga perkembangan keterampilan akademis terutama bidang menulis dan membaca. ${ }^{21}$

\section{F. Huruf Braille}

Braille merupakan sejenis tulisan-tulisan sentuh yang digunakan oleh tuna netra. Louis Braille sebagai orang Pernacis yang menciptakan system tersebut dikarenakan dari waktu kecil sudah mengalami kebutaan.

20 Ishartiwi, Mengenali Penyandang Difabel netra dan Pendidikanya, Yogyakarta: UNY, 2008), hlm. $1 . \quad$ Diaskses http://staff.uny.ac.id/sites/default/files/pengabdian/isthartiwimpddr/makalah.difabel netra.yakkum.pdf. tanggal akses 22 juli 2013.

21 Ahmad Nawawi, Pentingnya Orientasi dan Mobilitas bagi Difabel netra, Makalah Program Studi Pendidikan Kebutuhan Khusus (S2), (Bandung: Universitas Pendidikan Indonesia, 2009), hlm. 4 
Di Indonesia sendiri penggunaan tulisan Braille ini sejak tahun 1901 dengan didirikannya Blinden Institut (Lembaga Orang Buta) di Bandung oleh Dr. Westhoff. Hingga berakhirnya perang dunia II dan hingga sekarang system tulisan braille dari Negara Belanda yang diikuti oleh Indonesia. ${ }^{22}$

Huruf braille merupakan sebuah system yang bertujuan untuk menjelaskan sebuah angka, huruf dan symbol-simbol lainnya yang menggunakan pola penulisan kartu domino yang ditonjolkan dengan berdasarkan penulisan susunan enam titik yang terdiri dari dua titik horizontal dan tiga titik vertikal. ${ }^{23}$ Sistem tulisan braille mencapai taraf kesempurnaan di tahun $1836 .{ }^{24}$ Siswa difable netra hanya dapat mengoptimalkan alat pendengaran dan perabaan merekauntuk belajar. Bahkan untuk membaca, siswa difable netra memerlukan buku huruf khusus, yaitu huruf braille.

Tujuan diciptakan huruf braille adalah sebagai sumber belajar siswa difabel netra, serta mempermudah komunikasi yang terjadi anatar siswa maupun guru ketika kegiatan belajar mengajar berlangsung. Oleh sebab itu, buku teks awas merupakan bahan ajar bagi guru dan buku teks Braille merupakan sumber belajar siswa difabel netra, sehingga betapa pentingnya hiuruf Braille bagi siswa difable netra. Modul yang merupakan bahan ajar yang dirancang secara sistematis dan menarik yang bertujan untuk tercapainya kompetensi yang berisi materii, metode dan cara evaluasi.

${ }^{22}$ Dwijo Sumarno dan Purwanto, Pedoman Menulis Braille, (Yogyakarta: UNY, 1986), hlm 10.

${ }^{23}$ David J. Smith, Inklusi, Sekolah Ramah Untuk Semua, (Bandung: Nuansa, 2009), hlm 245

${ }^{24}$ Departemen Pendidikan dan Kebudayaan, Pedoman Tulisan Singkat Braille Indonesia, (Jakarta: Direktorat Jendral Pendidikan Dasar dan Menengah Departemen Pendidikan Kebudayaan, 1975), hlm 1. 
Software yang digunakan untuk mengkonversi huruf latin (awas) menjadi huruf barille disebut dengan software perky duck. Selain itu Software yang penggunaannya lebih praktis dalam mengkonversi baisanya terdapat di Sekolah Luar Biasa (SLB) dan instansi-instansi yang bisa mencetak huruf braille secara khusus.

Huruf yang dihasilakan dari ketikan braille dapat dilihat dengan meng-klik menu view, lalu pilih submenu print font. Secara sederhana, huruf braille dapat dibuat dengan menggunakan alat bernama Reglet. Hanya saja alat ini, lebih cocok digunakan bagi mereka yang sudah mahir huruf braille, misalnya siswa difable netra. Menulis braille dengan reglet, penulisannya menggunakan simbol braille negatif.

\section{G. Implementasi Pembelajaran IPA Berbasis Pendidikan Karakter Dengan Huruf Braille Untuk Siswa Difable Netra}

Berdasarkan data-data yang diperoleh dari penelitian ataupun penelitian-penelitian terdahulu dapat dijelaskan penerapan ataupun implementasi pembelajaran IPA berbasis pendidikan karakter dengan huruf braille untuk siswa difable netra terdapat tahp-tahap pelaksanaannya sebagai beriku.

\section{Tahap Perencanaan}

Pada tahap ini seorang guru melakukan perumusan tujuan pembelajaran dengan mengintegrasikan nilai-nilai pendidikan karakter kedalam Rencana Pelaksanaan Pembelajaran (RPP) materi pelajaran IPA. Didalam RPP harus mencakup Kompetensi Inti (KI) dan diuraikan secara rinci dalam Kompetensi Dasar (KD) untuk dapat menyeimbangkan dan tercapainya tiga aspek penting dari tujuan 
pembelajaran yaitu aspek sikap, pengetahuan dan keterampilan. ${ }^{25}$ Dalam merumuskan tujuan pembelajaran ini sangat perlu untuk melakukan perencanaan sesuai dengan pedoman khusus pembelajaran IPA untuk anak difabel netra. Seperti contoh dengan media pembelajaran khusus seperti salah satunya buku dengan huruf braille.

\section{Tahap Pelaksanaan}

Berdasarkan kondisi siswa yang hanya mampu menggunakan indera peraba dan indera pendengaran saja untuk mengikuti proses pembelaajaran dikelas maka semua media ataupun sumber belajar harus menyesuaikan kebutuhan siswa difabel netra. Pada penelitian sebelumnya ketika proses pembalajaran IPA sedang berlangsung diamati setiap sikap dan perilaku siswa yang muncul dari aktivitas anak sesuai pada tingkat kemampuan penglihatanya. Misalnya anak low visio dapat mengamati media dengan jarak dekat dan sambil meraba berdasarkan tekstur bentuk media tersebut, anak blind dapat mengamati media dengan jarak dekat akan tetapi harus adanya cahaya yang memadai dan sambil meraba berdasarkan tekstur bentuk media tersebut, dan anak totallyblind mengamati media dengan perabaan, pendengaran dan penciuman, dan melakukan meraba berdasarkan tekstur bentuk media tersebut. ${ }^{26}$

${ }^{25}$ Tika Meldina, Melinedri, Alfiana Agustin, dan Siti Hadijah Harahap, "Integrasi Pembelajaran IPS pada Kurikulum 2013 di Sekolab Dasar" AR-RLAYAH : Jurnal Pendidikan Dasar [Online], Volume 4 Number 1 (30 June 2020). http://journal.iaincurup.ac.id/index.php/JPD/article/view/1572

${ }^{26}$ Khamdun. Media Pembelajaran IPA Berbasis Alam Untuk Siswa Tunanetra dala Pendidikan Karakter. SEMINAR NASIONAL PENDIDIKAN SAINS Magister Pendidikan Sains dan Doktor Pendidikan IPA FKIP UNS. Surakarta, 19 November 2015. https://media.neliti.com/media/publications/173188-ID-none.pdf 


\section{Tahap Evaluasi}

Nilai-nilai karakter yang terdapat dalam pendidikan inklusi khususnya anak difael netra tidak memiliki perbedaan dengan anak awas hanya komunikasi ketika proses pembelajaran saja yang berbeda, oleh sebab itu perlu ada penambahan nilai karakter anak difabel netra berdasarkan tingkat adaya keterbatasan penglihatan dengan kepekaan inderawinya. "Anak difabel netra yang memiliki keterbatasan penglihatan perlu karakter anak difabel netra dalam upaya memotivasi dirinya dalam proses pembelajaran. Begitupula perilaku sehat yang dilakukan anak difabel netra juga harus diajarkan sedini mungkin supaya dalam kehidupan sehari-hari mengenal hidup sehat dan mengerti kebersihan lingkungan maupun diri sendiri. Suasana selama pembelajaran juga perlu ditumbuhkan dengan kondisi anak difabel netra yang gembira untuk membuat suasana belajar lebih kondusif." ${ }^{27}$

\section{KESIMPULAN}

Pembelajaran IPA berbasis pendidikan karakter ini menunjang tercapainya tujuan suatu pembelajaran dan mempermudah peserta didik untuk memahami materi pembelajaran yang didalamnya terdapat sentuhan-sentuhan nilai-nilai karakter seperti nilai disiplin, jujur, kerja keras, religius, jujur, mandiri, kreatif, dan nilai-nilai karakter lainnya dengan melalui proses pembelajaran dapat menjadikan anak tersebut mencintai dan mengagungkan ciptaan-Nya. Dengan penggunaan huruf braille yang bertujuan agar anak difabel netra membaca sumber belajar melalui indera perabaan dalam menggantikan kemampuan visual mereka.

Hasil dari penelitian ini diperolehnya pemaparan secara jelas

${ }^{27}$ Khamdun. Media Pembelajaran IP A..... 2017 
mengenai: A. Pendidikan karakter, B. Karakteristik kajian IPA, C. Pembelajaran IPA, D. Tujuan pembelajaran IPA, E. Anak berkebutuhan khusus, F. Huruf braille, G. Implementasi pembelajaran IPA berbasis pendidikan karakter dengan huruf braille untuk siswa difable netra bisa dilaksanakan dengan tiga tahapan, diantaranya: 1). Perencanaan terdiri dari perumusan tujuan pembelajaran, memilih dan mengemas materi dengan memasukan nilai-nilai pendidikan karakter kedalam RPP; 2). Pelaksanaan terdiri dari mata pelajaran IPA dan integrasi dengan mata pelajaran lainnya; 3). Evaluasi terdiri dari kegiatan penilaian yang berdasarkan penerapan nilai-nilai pendidikan karakter yang terimplementasi pada sikap dan perilaku siswa difabel netra di sekolah.

\section{DAFTAR PUSTAKA}

Azzet, Ahmad Muhaimin. 2011. Urgensi Pendidikan Karakter di Indonesia. Yogyakarta: Ar-Ruzz Media.

Delpie, Bandi. 2006. Pembelajaran Anak Tunagrahita: Suatu Pengantar Dalam Pendidikan Inklusi, Bandung: Aditama.

Departemen Pendidikan dan Kebudayaan. 1975. Pedoman Tulisan Singkat Braille Indonesia. Jakarta: Direktorat Jendral Pendidikan Dasar dan Menengah Departemen Pendidikan Kebudayaan.

Efendi, Mohammad. 2006. Pengantar Psikopedagogik Anak Berkelainan. Jakarta: Bumi Aksara."

Gunawan, Ary. H. 2000. Sosiologi Pendidikan: Suatu Analisa Sosiologi Tentang Pelbagai Problem Pendidikan. Jakarta: Rineka Cipta.

Ishartiwi. 2008. Mengenali Penyandang Difabel netra dan Pendidikanya. Yogyakarta: UNY, tanggal akses 22 juli 2013.

Khamdun. 2015. Media Pembelajaran IPA Berbasis Alam Untuk Siswa Tunanetra dala Pendidikan Karakter. SEMINAR NASIONAL PENDIDIKAN SAINS Magister Pendidikan Sains dan Doktor Pendidikan IPA FKIP UNS. Surakarta, 19 November 2017

Kirschenbaum, H. 1995. 100 Ways to Enhance Values and Morality in School and Youth Settings. Boston: Allyn \& Bacosn.

Meldina, T., Melinedri, M., Agustin, A., \& Harahap, S. 2020. Integrasi Pembelajaran IPS pada Kurikulum 2013 di Sekolah Dasar. ARRIAYAH: Jurnal Pendidikan Dasar. 
Nawawi, Ahmad. 2009. Pentingnya Orientasi dan Mobilitas bagi Difabel netra, Makalah Program Studi Pendidikan Kebutuhan Khusus (S2), Bandung: Universitas Pendidikan Indonesia.

Trianto. 2007. Wawasan Ilmu Alamiah Dasar (perspektif Islam dan Barat). Jakarta: Prestasi Pustaka.

. 2007. Model Pembelajaran Terpadu dalam Teori dan Praktikum. Jakarta: Prestasi Pustaka.

Sahlan, Asmawa dan Angga P. Teguh. 2012. Desain Pembelajaran Berbasis Pendidikan Karakter. Yogyakarta: Ar-Ruzz Media.

Smith, David J. 2009. Inklusi, Sekolah Ramah Untuk Semua. Bandung: Nuansa.

Somatri, Suljihati T. 2007. Psikologi Anak Luar Biasa, Bandung: Refika Aditama.

Suliyatno \& MM, S. 2017. Metode Penelitian Kuantitatif. Jakarta: Rineka Cipta.

Sulistyorini, Sri. 2007. Model Pembelajaran IPA Sekolah Dasar dan Penerapannya dalam KTSP.Yogyakarta: Tiara Wacana.

Sumarno, Dwijo dan Purwanto. 1986. Pedoman Menulis Braille. Yogyakarta: UNY.

Suyanto. 2011. Pendidikan Karakter dalam Prespektif Teori dan Praktik.Yogyakarta: UNY Press.

Undang - Undang No. 1 tahun 2003 tentang Sistem Pendidikan Nasional, pada Bab I pasal 1. Undang-Undang Sistem Pendidikan Nasional, Yogyakarta: Pustaka Pelajar

Widodo, Agus. 2011. Pendidikan Karakter Strategi Membangun Karakter Bangsa Beradaban. Yogyakarta: Pustaka Pelajar.

Zubaedi. 2004. Pendidiikan Berbasis Masyarakat Upaya Menawarkan Solusi Terhadap Bergbagai Probllem Sosial. Yogyakarta: Pustaka Pelajar.

Zuchdi, Darmayati. 2012. Model Pendidiikan Karakter Terintegrasi dalam Pembelajaran dan Pengembangan Kultur Sekolah. Yogyakarta: UNY Press. 